\title{
RELASI BAHASA SATIR DAN KRITIK SOSIAL DALAM CERPEN "LELUCON PARA KORUPTOR" KARYA AGUS NOOR
}

\author{
Radita Gora Tayibnapis \\ Program Studi Ilmu Komunikasi, Fakultas Ilmu sosial dan Ilmu Politik \\ Universitas Satya Negara Indonesia. \\ email: radita.gora026@gmail.com
}

\begin{abstract}
Abstrak
Fenomena kasus korupsi saat ini tidak lagi menjadi hal yang awam bagi masyarakat, namun di satu sisi kasus korupsi yang ada di Indonesia semakin lama memberikan daya tarik terendiri untuk diceritakan. Seperti halnya dilakukan oleh sastrawan Agus Noor dalam menuliskan tentang sebuah realitas koruptor di dalam penjara yang dikemas dalam bentuk satir yang sarat dengan kritik sosial. Berdasarkan hasil penelitian melalui analisis semiotika Hjlemslev menemukan bahwa bahasa satir yang digunakan dalam cerpen "Lelucon Para Koruptor" memberikan tanda-tanda khusus pada bahasa lelucon yang digunakan dengan penggambaran karakteristik korupsi dan adanya kuasa dominan sebagai representasi realitas dari kasus koruptor tersebut.
\end{abstract}

Kata Kunci: Satir, Kritik Sosial, Cerpen, Semiotika

\section{PENDAHULUAN}

Korupsi bisa dikatakan tidak lagi menjadi hal yang tabu, bahkan banyak yang mengatakan bahwa korupsi sudah membudaya di Indonesia ini meskipun tidak mudah untuk diidentifikasi dan terlarang. Jumlah koruptor di Indonesia pun mengalami peningkatan yang cukup menyedihkan, karena semakin banyak jumlah koruptor yang tertangkap oleh Komisi Pemberantasan Korupsi (KPK) hingga tahun 2019.

Hampir setiap hari berita-berita mengenai kasus korupsi selalu mewarnai media surat kabar dan kerap menjadi headline pada pemberitaan koran yang selalu terbit setiap pagi ataupun pemberitaan headline pada program tayangan berita televisi dan juga selalu menjadi sorotan media massa apabila ada terkuak tersangka-tersangka baru dalam sebuah kasus korupsi. Sehingga hal ini lah yang kemudiann membuat pemberitaan mengenai kasus korupsi ini menjadi menarik dihidangkan bagi khalayak saat ini.

Perilaku korupsi yang dianggap 
sebagai bagian dari kehidupan masyarakat ini kerap menjadi bahan bulan-bulanan bagi para kritikus politik, kritikus sosial, hingga kritik pada karya seni termasuk karya sastra. Cerita mengenai perilaku korupsi dan juga gambaran umum mengenai situasi masyarakat dan dilematis korupsi saat ini rupanya cukup mengundang perhatian serius dari para sastawan untuk dijadikan sebuah cerita yang unik. Hal ini yang biasanya dikemukakan dalam sebuah cerita fenomena ataupun sebuah satir atau sindirian yang bersifat kritik politis dari tindakan koruptif.

Awalnya pemberitaan mengenai kasus korupsi hanya dipandang sebagai sebuah cerita kriminal biasa seperti halnya cerita-cerita pencurian di media massa yang diberitakan dan dijadikan sebagai tersangka dan menjadi bagian dari pelanggar KUHP. Namun berita seputar kehidupan para koruptor ini pun menjadi berkembang menjadi sebuah pendalaman feature di media massa seperti kehidupan mewah para koruptor dalam kehidupan sehari-hari, kemudian cerita para koruptor di media massa yang seharusnya berada di dalam sel penjara, namun kepergok sedang berada diluar sel sedang melakukan aktivitas dan makan diluar. Selain itu juga mencakup cerita para koruptor di dalam penjara yang ruangannya didesain seperti kamar kos atau seperti hotel.

Kritik mendalam tentang perilaku korupsi kerapkali digambarkan secara riil dan mengenai kenyataan yang memang terlihat dipermukaan yang disajikan dalam bentuk pemberitaan di media massa. Sehingga khalayak pun pada akhirnya juga lebih menyukai dan mempercayai isi pemberitaan dibandignakan untuk melihat suatu peristiwa korupsi dari sudut pandang yang berbeda.

Dalam sebuah kisah korupsi di pemberitaan media massa menghadirkan praktik korupsi yang terjadi terus-menerus. Bisa dikatakan bahwa praktik korupsi makin pejal setelah era reformasi ini. Tentunya hal ini yang juga menjadi masalah demokratis bagi negara di satu sisi gejolak politik pun terus berkelanjutan bagi semua pihak terutama yang ada di dalam institusi pemerintahan.

Hal ini lah yang kemudian menjadikan kesempatan bagi para sastrawan atau kolumnis untuk memuat cerita-cerita mengenai kasus korupsi dari sudut pandang yang berbeda, bahkan anyak hal yang sebenarnya untuk dijadikan sebagai sesuatu hal yang tabu, sesuatu yang diketahui oleh para sastrawan namun tidak banyak diketahui oleh orang kebanyakan. Hal ini pula yang kemudian membuat seorang sastrawan kemudian tidak ingin terlalu terbuka dalam mengemukakan interpretasinya mengenai sebuah fenomena kasus korupsi yang tidak dilihat dari sisi sudut pandang media massa.

Argumen dari seorang sastrawan pun sering dijadikan sebagai bagian dari 'bumbu penyedap' dalam rangkaian tulisan disebuah surat kabar. Hal ini yang mendorong para sastrawan kemudian untuk mengulas beragam cerita-cerita unik dari sudut pandangnya untuk dijadikan sebagai tulisan opini yang dirangkai dalam sebuah cerita pendek yang mengkombinasikan dengan bentuk kelakar. Terkadang di surat kabar bentuk-bentuk kelakar semacam ini sering dijadikan sebagai penghias cerita yang menarik untuk mencegah kebosanan pembaca agar tidak melulu disuguhi ceritacerita yang serius dan berat. Sehingga penting bagi para kolumnis ataupun 
sastrawan yang mengisi kolom esai di surat kabar ataupun di dalam situs web.

Kumpulan-kumpulan cerita dalam bentuk cerita pendek yang ditulis oleh para sastrawan ini pun tanpa terasa bila dituliskan terus-menerus menjadi sebuah kumpulan cerita atau opini berupa ulasan kritik politis atau kritik sosial yang dikemas juga dalam sebuah cerita pendek yang disamarkan dari sebuah kisah nyata hingga hanya terlihat sebagai cerita fiksi.

Seperti halnya yang dilakukan oleh Agus Noor melalui bukunya berjudul "Lelucon Para Koruptor" yang dikemas dalam bentuk cerita pendek yang menggambarkan tentang situasi sosial saat ini dan juga cerita sindirian (satir) tentang tindakan terselubung pelaku korupsi selama di penjara serta tindakan-tindakan dari kelompok dominan yang menunjukkan kekuasaan dalam sebuah tindakan yang negatif.

Satir yang dikemas pun bermacammacam, ada yang memang secara terangterangan untuk mengungkap sindiran dalam bentuk cerita panjang atau dalam cerita yang datar tentang sebuah kehidupan, namun adapula yang menceritakan satir dalam bentuk lelucon yang sebenarnya berisi sindiran yang dikemas dalam sebuah cerita dan menunjukkan bahwa masih terdapat kekuasaan dominan dari praktik korupsi tertutama yang membedakan para terpidana korupsi dibandingkan kasus pidana diluar korupsi.

Sehingga dalam cerpen ini menjadi sebuah Mimikri atau dalam pengertian sederhana adalah sikap penyesuaian diri dengan lingkungan atau keadaan untuk melindungi diri. Banyak yang memandang bahwa cerpen-cerpn yang memihak mimesis, jelas muskil ntuk melerai pijar celoteh, satire, pamflet, makian, dan lainlain seringkali diangga biasa atau normal belaka sebagai pilat-pilar bangunan kritiknya.

Seperti halnya humor satir dari karya Agus Noor ini yang secara terbuka dan seperti menampilkan tarnsparansi kehidupan koruptor yang mencoba menggali dari berbagai informasiang dikumpulkan tentang kehidupan para koruptor di penjara. Hal ini yang kemudian juga sempat mengundang kritik dan kontroversi terutama sindiran kepada pihak penjagaan aparat di penjara. Sehingga cerpen ini pun menjadi perbincangan yang negatif dikalangan aparat kejaksaan yang bertugas sebagai sipir penjara yang dinilai mudah untuk mendapatkan gratifikasi dan sogokan dari para terpidana korupsi, dan juga memberikan kelonggaran kepada para koruptor untuk leluasa merasakan kenikmata dalam penjara dan mendapat perlakuan istimewa.

Meskipun tidak sampai pada tuntutan di ranah hukum, namun karya seni seperti karya sastra semacam ini masih dianggap normal sebagai sebuh karya sastra, yang dimana sebuah kebebasan berpendapat dan juga kebebasan berkarya yang menjadi hak kepada setiap orang untuk melimpahkan caranya berpesan baik melalui karya-karya seni seperti seni luukis atau senin sasra dan dengan gaya apapun yang juga menjadi bagian yang menarik untuk dikaji secara ilmiah. Sehingga disini karya sastra seperti yang dibuat oleh Agus Noor merupakan sebuah karya sastra yang didasarkan pada sebuah realitas yang kemudian dikemas secara abstrak, bahasa yang lugas meskipun tidak menyinggung sala salah satu pihak secara terang-terang dan diulas dengan gaya bahasa perpaduan dialog dan naratif yang 
menarik dan unik seperti halnya dengan gaya humor berupa lelucon.

Humor-humor politik bisa dikatakan sebuah ungkapan yang diceritakan oleh penulis yang mencoba menceritakannya dengan gaya bahasanya sendiri dan juga divariasikan dengan ragam gaya bahasa unik serta humor dengan berbagai lelucon yang sekedar menjadikan sebuah cerita hiburan bagi pembacanya. Namun bagi para penulis sastra lelucon dan humor terkadang bukan hanya sekedar candaan yang bertujuan menghibur melainkan ada sindiran-sindiran yang memuat informasi dan gambaran sebuah realitas yang tidak pernah diketaui orang awam, seringkali pesan-pesan tersebut tersirat makna-makna yang terbungkus dalam sebuah bahasa yang abstrak dan bahkan ambigu.

Hal ini lah yang terdapat dalam karya cerpen "Lelucon Para Koruptor" karya Agus Noor yang termuat beragam gambaran tentang kehidupan koruptor yang sebenarnya mencoba menginformasikan sebauh realitas yang tidak diketahui oleh banyak orang, namun tidak diulas dalam cara yang terbuka dan mencoba menggambarkan tentang sebuah kekuatan kelompok dominan dari para koruptor. Sehingga hal ini lah yang kemudian menjadi persoalan yang cukup kontroversi bagi tatanan politik maupun aparat. Sehingga urgensi dalam penelitian ini adalah keberadaan lelucon kini dalam ranah bahasa tidak lagi menjadi sarana hiburan dalam sebuah bacaan karya sastra, melainkan lelucon sebagai bagian dari instrumen bahasa yang bertujuan sebagai doxa dalam pasar bahasa untuk mendominasi tata wacana bagi publik.

Berdasarkan rumusan masalah yang telah dijelaskan sebelumnya, maka dalam penelitian ini berupaya untuk menelusuri struktur dan gaya bahasa satir dalam cerpen "Lelucon Para Koruptor", serta menemukan relasinya dalam membongkar kritik kritik sosial yang termuat di dalam cerpen tersebut. Sehingga pertanyaan penelitian yang ada dalam peneltian ini adalah "Bagaimana relasi dan kritik kritik sosial digambarkan dalam cerpen "Lelucon Para Koruptor"?.

Adapun dalam tujuan penelitian ini adalah "untuk menemukan relasi dalam kritik sosial yang dikisahkan dalam cerpen Lelucon Para Koruptor karya Agus Noor".

Gaya bahasa yang digunakan oleh para sastrawan biasanya menggunakan penyamaran dalam bentuk lelucon, masih tetap dilakukan dalam kepantasan untuk menghindarkan inhibisi (hambatan) internal dalam pikiran sang pencerita lelucon tersebut. Lelucon seringkali dianggap sebagai sesuatu yang benar sebagai cara untuk mengungkapkan sesuatu yang biasanya dilarang leh masyarakat. Menurut Freud dalam atas lelucon paralel dengan pendekatanny, bahwa terlacak adanya mekanisme yang berbeda-beda dalam kerja lelucon, yakni: (Ajidarma, 2012). (1) kondensasi: dibentuknya susunan kata, atau suatu kata diubah sesuaikan; (2) repetisi: materi yang ama digunakan dengan berbagai cara berbeda selama menyampaikan lelucon; (3) makna ganda: lelucon yang bermain atas kata-kata dan suatu hal digunakan untuk menghadirkan kembali yang lain.

Konsep makna memungkinkan dua interpretasi yang merefleksikan dialektika pokok antara peristiwa dan makna. Memaknai sesuatu ucapan berarti apa yang dimaksudkan oleh pembicara, yaitu apa yang ingin dikatakan (maksud) pembicara 
Radita Gora Tayibnapis: Relasi Bahasa Satir dan Kritik Sosial dalam Cerpen "Lelucon Para Koruptor" Karya Agus Noor

Website : https://jurnal.umj.ac.id/index.php/penaliterasiEmail : penaliterasi@umj.ac.id

tersebut, dan apa makna kalimat itu sendiri yakni apa hubungan antara fungsi identifikasi dan fungsi predikat. Dengan kata lain, makna adalah baik bersifat noetik maupun noematik. Kita dapat menghubungkan referensi wacana ke pekbicaranya melalui suatu peristiwa dari dialektika itu. Peristiwa adalah seseorang yang berbicara. Dalam artian ini, sistem atau tanda bersifat anonim dalam wilayah yang semata bersifat virtual. (Ricouer, 2014)

Masih menurut Ricouer (2014), dalam sistem bahasa sebagai suatu bentuk leksikon, tidak ada masalah dengan referensi; tanda hanya mengacu kepada tanda lain dalam satu sistem. Namun begitu, dengan kalimat bahasa diarahkan pada hal di balik dirinya sendiri. Di mana makna bersifat immanen terhdap wacana, dan tentunay bersifat objektif dalam makna ideal, referensi justri mengekspresikan adanya pergerakan di mana bahasa mentransendensikan adanya pergerakan di mana bahasa mentransendensikan dirinya sendiri.

Sedangkan menurut Koestler yang memeriksa humor sebagai bagian dari obsesinya terhadap kerja tindakan kreatif. Baginya, jika seniman memperlakukan fakta sebagai rangsangan bagi imajinasi, dan ilmuwan menggunakan imajinasinya untuk mengatur fakta, maka dinyatakannya bahwa perbedaan itu tidak fundamental, dan bahwa segenap kegiatan kreatif manusia berdasarkan pola yang sama, yang juga berlaku bagi humor. (Ajidarma, 2012)

Dalam karya lelucon kerap memunculkan sebuah citra, simbol, dan metafor yang bertujuan untuk memberikan gaya baru dalam penyampaian sebuah cerita kepada pembacanya. Dalam psikologi sastra dijelaskan bahwa citra adalah reproduksi mental, suatu ingatan masa lalu yang bersifat indrawi dan berdasarkan persepsi, tidak selalu bersifat visual. (Wellek dan Warren, 2016)

Menurut I.A. Richards dalam bukunya, Principles of Literary Criticism (1924), mengatakan bahwa:

"Kualitas inderawi dari citra terlalu dianggap penting. Yang membuat suatu citra efektif adalah kejelasaannya sebagai citra, bukan sifatnya sebagai suatu peristiwa mental yang secara khusus berkaitan dengan pengindraan."

Pencitraan sebagai perwujudan kembali bekas-bekas pengindraan, selain itu sebagai analogi dan perbandingan. Sehingga "citra" atau "imaji" yang melahirkan aliran imajisme, "simbol" juga melahirkan suatu aliran sastra, yaitu simbolisme. Seperti citra, simbol muncul dalam konteks yang sangat beragam dan digunakan untuk berbagai tujuan. Simbol aljabar dan logika adalah tanda konvensional yang disetujui bersama. Simbol selalu secara terus-menerus menampilkan dirinya. Suatu citra dapat dibangkitkan melalui sebuah "metafora". Tetapi jika citra itu terus-menerus muncul sebagai suatu perwujudan yang mewakili sesuatu, citra itu pun menjadi simbol dan bahkan dapat menjadi bagian dari sistem yang simbolis, sistem yang mengandung mitos. (Wellek dan Warren, 2016)

Upaya untuk menemukan makna sebuah simbol dalam sebauh cerita dan juga metafora (ungkapan), maka perlu bagi peneliti untuk menjelaskan signifikansi tanda-tanda yang digunakan dalam sebuah cerita. Menurut Hjelmslev, tanda-tanda tidak dapat dibangun secara sederhana 
sebagai kombinasi diferensial dari penanda dan petanda. Ia pun menegaskan hakikat dari sebuah tanda dalam koneksi logisnya dengan tanda-tanda lain. Menurutnya logika Saussrean dan diferensiasi either/or (korelasi) membatasi sebuah sistem yang tidak lengkap. Ia (Hjelmslev) juga mengusulkan bahwa diferensiasi both/and mempertahankan relasi dalam sbeuah proses. Baginya, sebuah tanda merupakan self-reflexive dalam arti bahwa penanda dan petanda secara konsekuensial membentuk kemampuan dari ekspresi dan persepsi. Hjlemslev beranggapan bahwa fungsi simbolik bahasa memuat representasi eidetik dan representasi empiris dari pemaknaan. (Rusmana, 2014)

Masih menurut Hjlemslev dalam Rusmana (2014), bahasa mempunyai dua sistem (dyadic system), yaitu segi expression (Ekspresi); dan segi content (Isi). Dua istilah ini sejajar dengan signifier dan signified. Apabila sei ekspresi adalah segi seleksi kata-kata (rangkaian signifer), rangkaian kata-kata dapat memberi makna khusus (signified). Hjlemslev juga mengatakan bahwa selain ekspresi dan isi, bahasa juga mempunyai segi lain, yaitu form (bentuk) dan substance (substansi). Form (bentuk) adalah apa yang diberi kepada kata yang dipakainya atau apa yang dapat diberikan secara lengkap, sederhana, dan koheren. (Rusmana, 2014)

Melalui bentuk yang dipilih oleh penulis atau pembicara, suatu kata mempunyai arti dan makna, sehingga dalam sistem bahasa beroperasi empat unsur, yaitu expression form (bentuk ekspresi), content form (bentuk isi), expression substance (substansi ekspresi), content substance (substansi isi). Hjlemslev memberikan metafora bahwa form ibarat jala yang dilempar kelaut, pada saat pelemparan terlihat bayangan jala yang diibaratkan sebagai substance yang memeberikan batasan hamparan laut. Dalam perluasan ini diperoleh gambaran bahwa sebelum expresiion form terbentuk, terdapat bahan tanpa bentuk yang melalui expression substance memperoleh batasan yang akhirnya terwujud dalam expression form. Expression Form (bentuk ekspresi) tersusun dari kaidah-kaidah paradigmatik dan sintagmatik, sedangkan expression substance (bentuk isi) merupakan organisasi formal petanda-petanda melalui hadir tidaknya marka semantik. (Rusmana, 2014)

Hjlemslev melihat bahwa tetap adanya penjabaran bahasa sebagai objek utama lingustik, solusinya hampir dapat dipastikan komphrehensif dan holistik. Untuk menandai perbedaannya dari pendekatan studi linguistik, Hjlemslev mengusulkan gagasan Glosematika atau dapat disebut juga dengan aljabar bahasa yang bekerja dengan berbagai entitas tanpa nama, imu yang objeknya aljabar bahasa yang imanen.

Konsep yang digunakan dalam Glosematika diantaranya adalah konsep katalis. Konsep ini beroposisi dengan analisis jika analisis bersifat memilah-milah hal yang terobservasi langsung, katalis melibatkan penyusunan atas hal-hal yang tidak dapat diobservasi secara langsung. Katalis mengiedntifikasi enanda dibalik "substansi" yang secara langsung dapat diakses melalui pengamatan indrawi.

\section{METODE PENELITIAN}

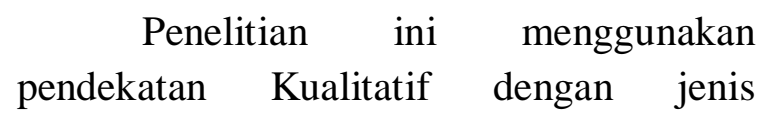


penelitian Deskriptif. Paradigma konstruktivis digunakan dalam penelitian ini. Metode yang digunakan dalam penelitian berupa interpretasi teks dengan menggunakan metode Semiotika. Semiotika sebagai suatu model dari ilmu pengetahuan sosial, memahami dunia sebagai suatu sistem hubungan yang memiliki unit dasar dengan 'tanda'. Menurut Umberto Eco, tanda sebagai suatu 'kebohongan' dan dalam tanda ada sesuatu yang tersembunyi di baliknya dan bukan merupakan tanda itu sendiri. Tanda merupakan cerminan dari realitas yang dikonstruksikan lewat katakata. (Wibowo, 2013)

Saat memahami teks sastra, seringkali kita dihadapkan pada tanda-tanda yang bervariasi, yang perlu diinterpretasikan dan dikaji ada apa di balik tanda-tanda itu. Tanda itu merupakan cerminan dari realitas, yang dikonstruksikan lewat kata-kata. Menurut Saussure, persepsi dan pandangan kita entang realitas, dikonstruksikan oleh katakata dan tanda-tanda lain yang digunakan dalam konteks sosial.

Korpus penelitian yang digunakan dalam penelitian ini berupa Cerpen berjudul "Lelucon Karya Agus Noor" setebal 16 halaman. Adapun data sekunder di koneksikan ssebagai data primer dalam penelitian ini yaitu teks sastra pada cerita pendek yang menjadi sampel penelitian dijadikan sebagai objek utama penelitian. Sedangkan tempat penelitian di lakukan di Jakarta, serta didukung oleh data sekuner berupa pernyataan dari penulis cerpen. Penelitian ini memfokuskan pada teks tulisan cerpen sebagai objek utama penelitian yang akan dianalisis dengan menggunakan analisis teks kualitatif dengan Semiotika.
Metode analisis data menggunakan analisis semiotika dengan model semiotika Hjlemslev. Pada model ini menskemakan tahapan Semiotika Konotatif, Semiotika Denotatif, kemudian menjadi Metasemiotika. Hjlemslev mengatakan bahwa semiotika denotatif adalah semiotika yang bidangnya bukanlah semiotika, sedangkan semiotiika konotatif adalah semiotika yang bidangnya bersifat semiotik. Sekalipun demikian, realitasnya tidak sesederhana itu. Ranah kajian pun dapat menjadi semiotik. Menurut Hjelmslev, hal ini disebut sebagai "metasemiotika". Metasemiotik dimaksudkan sebagai bentuk penghbungan tanda-tanda dalam teks (sastra) sebagai fakta semiotis hingga membuahkan gambaran semiotisnya. (Sobur, 2006)

Oleh karena itu Hjlemslev mencanagkan metasemiotik sebagai scientific semiotic yaitu sebagai rekonstruksi sistemis yang memiliki beberapa karakter seperti dilakukan intepreternya dan mengandung hubungan multiplanar, dalam arti tanda dalam teks mempunyai hubungan antartanda dalam teks dan intertekstualitas (memiliki jaringan hubungan dengan subsistem yang lain secara eksternal), dan dalam kesadaran batin interpreter, metasemiotik ada sebagai lambang kebahasaan yang memiliki kerangka hubungan secara internal maupun eksternal. Metasemiotik sebagai rekonstruksi interpreter tidak mempunyai pengetahuan tentang sistem tanda yang ditafsirkannya dan tidak mamu mengadakan formulasi dan rekonstruksi.

Analisis data dilakukan dengan identifikasi tanda-tanda pada teks cerpen "Lelucon para Koruptor" kemudian menganalisa petanda dan penanda pada fungsi tanda teks, 
Radita Gora Tayibnapis: Relasi Bahasa Satir dan Kritik Sosial dalam Cerpen "Lelucon Para Koruptor" Karya Agus Noor

Website : https://jurnal.umj.ac.id/index.php/penaliterasiEmail : penaliterasi@umj.ac.id

kemudian menginterpretasikan makna denotatif dan konotatif pada teks, kemudian konotatif teks dilihat dalam ungkapan (Metafor) yang kemudian dilihat makna atau kandungan pada teks ungkapan tersebut.

\section{HASIL DAN PEMBAHASAN}

Humor satir yang dituliskan Agus Noor dalam novelnya "Lelucon Para Koruptor" yang setebal 16 halaman merupakan salah satu cerpen dengan judul yang sama terletak pada halaman 120 - 138 . Fokus pada penelitian ini yaitu objek teks tetrtulis yang keseluruhan merupakan cerita kehidupan koruptor ketika berada di dalam sel penjara.

Pada cerpen ini terbagi menjadi tiga babak. Pada babak pertama adalah perbincangan antara seorang koruptor bernama Otok sebagai pemeran utama dalam cerita "Lelucon Para Koruptor", sebagai tokoh yang ditetapkan sebagai tersangka korupsi dalam sebuah kasus, berbincang dengan pengacaranya bernama Join Sembiling, SH, namun dalam cerita ini si pengacara berpengalaman menangani kasus-kasus korupsi. Pada babak cerita ini yang memadukan antara dialog dan naratif.

Pada percakapan antara kedua tokoh ini terdapat tanda-tanda pada kalimat teks yang mengandung unsur metafor baik dari segi naratif maupun dialog. Adapun dalam percakapannya sebagai berikut:

"Percayalah penjara bukanlah tempat yang menyeramkan bagi para Koruptor," katanya setengah tertawa.

Pada penggunaan kata "Percayalah" ini memiliki makna denotatif merupakan meyakini perkataan dan berharap meng "iya" kan pertakaan yang telah disampaikan oleh komunikator yaitu si Pengacara yang disampaikan kepada Komunikan atau si Otok.

Namun pada makna Konotasi nya bahwa kata ini tidak dimaknai sebaliknya, melainkan kata "Percayalah" pada cerpen ini menjelaskan tentang ada makna tersendiri dari dorongan kata "percaya" yaitu ada sesuatu yang berbeda yang ditawarkan kepada tokoh utamanya, yang dimana, dari yang "ditawarkan" tersebut bersifat positif tidak bersifat menakutkan, selain itu itu juga memiliki anggapan yang meyakinkan.

Sementara itu pada kalimat "penjara bukanlah tempat yang menyeramkan bagi koruptor". Secara denotatif penjara adalah tempat yang sangat menakutkan terutama bagi semua orang yang telah melakukan pelanggaran hukum atau ditetapkan sebagai tersangka pidana karena telah melakukan suatu perbuatan jahat dan tempat orang untuk mempertanggung jawabkan perbuatannya yang buruk. Sehingga secara konotasi umum dalam penjara adalah tempat yang negatif untuk para penjahat.

Dalam cerpen ini justru Konotasi ini berbeda dengan konotasi pada umumnya. Pada makna konotasinya penjara justru sebagai tempat yang menyenangkan, namun dalam hal ini terspesifikasikan khusus bagi penjahat terpidana koruptor bukan penjahat pada umumnya. Sehingga dalam hal ini justru dimaknai sebagai tempat yang nyaman untuk para koruptor karena dinilai sebagai tempat yang eksklusif.

Tidak seperti anggapan penjara yang membuat terpidana kehilangan kebebasan, membuat penghuninya merasa tertekan, dengan kehidupan yang membosankan dan akan mudah mati kesepian. Seperti dalam salah satu kalimat naratif pada cerpen 
Radita Gora Tayibnapis: Relasi Bahasa Satir dan Kritik Sosial dalam Cerpen "Lelucon Para Koruptor" Karya Agus Noor

Website : https://jurnal.umj.ac.id/index.php/penaliterasiEmail : penaliterasi@umj.ac.id

"Kehilangan kebebasan, bagaimanapun membuat Otok merasa tertekan. Ia membayangkan kehidupan yang begitu membosankan dan akan mati kesepian."

Dalam kalimat ini merupakan anggapan umum dan normatif dalam pandangan orang awam sekalipun yang membayangkan tentang kehidupan di penjara yang sebenarnya. Namun pada cerita ini, justru menjadi makna sebaliknya dalam makna Konotasinya yang tidak sesuai dengan idealnya makna penjara secara umum.

Makna ini juga dipertegas pada "sumber yang berbicara" dalam akhir kalimat "Katanya setengah tertawa". Penggunaan katanya ditujukan kepada "Pengacara" karena pada babak ini, hanya satu toko yang berbicara yaitu si Pengacara, sementara tokoh satunya tidak berbicara.

Sehingga makna keseluruhan pada kalimat ini menjelaskan bahwa penjara adalah tempat yang ditawarkan secara meyakinkan kepada tersangka koruptor yang bersifat positif serta tidak menakutkan, bahkan ditawarkan secara menyenangkan. Namun tempat penjara seperti ini hanya dikhususkan bagi para tersangka pidana korupsi yang notabene memiliki banyak finansial untuk membeli kenyamanan dalam penjara.

Pemaknaan diatas sejalan dengan penceritaan kalimat berikutnya yaitu:

"Anggap saja kau hanya pindah tempat tidur. Kau tetap bisa menjalankan bisnismu dan menikmati hal-hal yang kau sukai seperti biasanya."

Pada kalimat "Anggap saja kau hanya pindah tempat tidur". Kalimat ini seperti diucapkan secara ringan. Ibarat "semudah membalik telapak tangan". Meng "Anggap saja" berarti merasakan secara subjektif yang imajinatif (berimajinasi) sendiri untuk membuat orang tersebut lebih nyaman dan tidak menganggap situasi yang ada sebagai situasi yang sebenarnya, melainkan situasi yang ada sebagai dianggap sesuatu "yang lain" (The Others) yang membuat si subjek merasa lebih nyaman, meskipun hanya dalam pikirannya.

Kata ini dihubungkan dengan " $k a u$ hanya pindah tempat tidur". Pada kata "Tempat tidur" adalah tempat beristirahat secara terlentang dan mengutamakan kenyamanan beristirahat. Secara denotatif makna ini dapat diartikan sebagai pindah tempat tidur dari satu tempat ke tempat yang lain, dalam makna sebenarnya adalah dari satu kasur ke kasur yang lain yang dimaknai secara fisik. Sementara itu pada makna Konotasi disini "pindah tempat tidur" adalah berpindah situasi untuk segala hal termasuk tempat beristirahat. Awal perpindahan dimaksudkan untuk berpindah dri situasi lingkungan tempat tinggal atau lingkungan keluarga, berpindah pada lingkungan tempat tinggal yang lain dan tempat lingkungan sosial yang berbeda.

Dalam makna ini penjara sebagai tempat lingkungan sosial yang baru dan lingkungan tempat tinggal baru dengan suasana yang berbeda serta digambarkan sebagai sarana yang masih ditempatkan nyaman bagi tersangka koruptor termasuk tempat kerja baru bagi tersangka koruptor. Pemaknaan ini sejalan dengan kalimat berikutnya "Kau tetap bisa menjalankan bisnismu." Dalam makna ini menjelaskan bahwa tersangka koruptor masih bisa menjalankan usaha atau bisnisnya yang seharusnya menjalankan bisnis dilakukan diluar penjara.

Pada makna denotatif "menjalankan bisnis" berarti makna sebenarnya bahwa 
ada perihal bisnis atau urusan semacam urusan pribadi atau mendirikan usaha semacam perusahaan yang mendatangkan keuntungan. Dalam bagian cerita ini, makna denoatif bisnis diartikan sebagai usaha mencari keuntungan melalui sebuah perusahaan yang didirikan oleh si tersangka korupsi.

Dalam makna ideal sebuah bisnis seharusnya dijalankan secara bebas diluar penjara dan bukan di dalam penjara. Hal ini lah yang kemudian memiliki makna konotasi yang berbeda dari "tetap menjalankan bisnis", padahal si tokoh utama yang sebagai tersangka kasus korupsi justru sedang berada di penjara, namun hal tersebut tidak menghalangi si tokoh utama untuk menjalankan bisnisnya dari dalam penjara. Dengan kata lain bahwa, bisnis yang dijalankan dari dalam penjara tersebut masih tetap mendapatkan keuntungan. Sehingga, dapat makna bahwa penjara tidak menjadikan si koruptor menjadi miskisn, melainkan tetap menjadikan koruptor sebagai wadah orang berbisnis meskipun tidak bebas dan masih mendapatkan keuntungan finansial dari dalam penjara.

Hal ini pun dipertegas dengan kalimt lanjutannya "dan menikmati hal-hal yang kau sukai seperti biasanya." Penggunaan kata "Dan" sebagai kata penghubung memiliki makna bahwa tokoh utama yang dipenjara bukan hanya masih mendapat profit dari berbisnis, melainkan penjara yang ditawarkan masih menawarkan kesenangannya dan menjamin seolah penjara adalah tempat untuk bersenang-senang bukan untuk bersusah payah. Kalimat ini sejalan dengan makna sebelumnya bahwa penjara bukan tempat yang menyeramkan bagi koruptor, melainkan tempat yang menyenangkan karena masih ada tempat untuk berbisnis.

Selain itu, meski koruptor menjalankan masa hukumannya di penjara, namun tidak menutup kemungkinan bahwa anak dan istrinya masih mendapatkan jaminan pembiayaan diluar. Seperti halnya terangkai dalam kalimat berikut:

"Ada rekening khusus yang disiapkan buat istri dan anak-anakmu," begitu kesepakatan yang diatur Join Sembiling.

Secara denotasi bahwa rekening sebagai tempat tabungan orang-perorangan ataupun organisasi. Dalam kata "rekening khusus" dapat dikatakan sebagai tempat tabungan yang ditujukan pada orang tertentu. Pada makna konotasinya adalah, meskipun si Otok, tersangka korupsi berada di dalam penjara, namun jaminan hidup istri dan anaknya tetap ada. Hal ini sinkron dalam cerita bahwa Otok masih bisa menjalankan bisnisnya dari dalam penjara dan dari bisnis itulah Otok mampu menhidupi anak dan istrinya meskipun berada di dalam penjara.

Pemberian perlaku istimewa kepada napi koruptor pun bukan didasarkan atas kepentingan pribadi. Dalam akhir teks tertulis "begitu kesepakatan yang diatur Join Sembiling." dalam hal ini, pengacara mengambil peranan penting dalam setting kondisi di penjara napi untuk melindungi kliennya dengan membuat suatu setting dan kesepakatan agar kliennya di dalam penjara tetap terlindungi dan merasakan kenyamanan.

Dalam makna konotasi, kata "kesepakatan" dalam novel ini menceritakan bahwa kesepakatan tersebut merupakan suat perjanjian bahwa klien koruptor tetap terjaga keberadaannya selama berada di dalam sel lapas karena ada perjanjian khusus antara si Otok dengan Join yang dilakukan secara terselubung dan 
tak langsung.

Pesan-pesan terselubung termuat di dalam cerpen ini yang sebenarnya mencoba merepresentasikan kondisi latar belakang dari para koruptor yang dipenjara. Seperti halnya dalam kalimat berikut:

"Kawan-kawan dan atasan yang merasa diselamatkannya karena ia tak menyebutkan nama mereka selama persidangan akan membantu semua kebutuhan rumah tangganya, sebagai 'ucapan terma kasih'.

Meski mencoba menguraikan secara tersirat, namun dibalik tulisan ini, penulis terlihat memiliki pesan terselubung bahwa adanya praktik korupsi ada keterlibatan pihak lain yang dilindungi. Dalam sebuah makna denotasi "Kawan-kawan dan atasan yang merasa diselamatkannya karena ia tak menyebutkan nama mereka selama persidangan"

Apabila membaca kalimat "Kawankawan dan atasan yang merasa diselamatkannya". Penggunaan kata "di" dari kata "diselamatkannya" dapat diartikan bahwa adanya upaya penyelamatan yang dilakukan oleh tokoh yang merujuk pada penulisan dengan kata "nya" yang merujuk pada tokoh utama dalam cerita cerpen ini, yaitu penyelamatan orang lain. "selamatkan" dalam makna denotasi dapat diartikan sebagai upaya untuk memberikan rasa aman dan menghindarkan segala hal dari keburukan atau hal yang membahayakan. Dalam makna konotasi pada cerpen ini, kata "selamatkan" dapat bermakna ambigu bahwa ada rasa penyelamatan terhadap orang lain atau memberikan rasa aman dari orang lain yang didasarkan pada sebuah kepentingan.

Sehinga dapat dimaknai bahwa penetapan sebagai tersangka korupsi dan masuk penjara bisa jadi bahwa hal ini sebagai upaya penyelamatan diri orang lain dengan adanya pemberian imbalan, jaminan kehidupan dan lain sebagainya. Namun sebenarnya keberadaan Otok sebagai tersangka korupsi yang masuk ke penjara koruptor bisa dikatakan bahwa dirinya memang tidak bersalah dan bukan koruptor sebenarnya.

Hal ini dikatakan bahwa dalam pemaknaan teks diatas dapat diartikan bahwa Otok sebenarnya hanyalah sebagai "tumbal" dari sindikat korupsi yang pelaku sebenarnya tidak diketahui identitasnya lantaran idak dijelaskan dalam cerpen, namun sudah mengindikasikan di awal bahwa otok bukanlah sebagai pelaku, melainkan masuk penjara sebagai upaya melindungi orang lain dengan imbalan pemberian kehidupan yang nyaman di dalam penjara, kehidupan yang lebih baik untuk anak dan istri, serta jaminan uang dari rekening khusus dan membiarkannya menjalankan bisnisnya dari penjara.

Penegasan makna diatas dapat dilihat dalam kalimat "karena ia tak menyebutkan nama mereka selama persidangan." Di dalam persidangan selalu ada proses investigasi terhadap tersangka seperti menanykan siapa saja yang terlibat dalam kasus korupsi, dan jaringan mana saja yang ikut dalam sindikat tindak korupsi, termasuk menanyakan nama-namanya secara terbuka dihadapan pengadilan. Dalam konotasi nya, "karena ia tak menyebutkan nama mereka" dapat diartikan bahwa ada unsur kesengajaan untuk tidak memberikan sebuah nama kepada orang lain.

Apabila dikaitkan dengan makna sebelumnya, semakin terlihat jelas bahwa adanya upaya melindungi yang dilakukan 
oleh tokoh utama untuk melindungi tokoh lain. Ditegaskan pula dalam kalimat "akan membantu semua kebutuhan rumah tangganya, sebagai “ucapan terma kasih.” Pengucapan "Terima Kasih" dapat dikatakan sebagai ungkapan dari tindakan yang diberikan kepada dirinya seperti halnya imbalan namun hanya berupa katakata saja. Namun dalam makna konotasi pada cerita ini, "terima kasih" dapat bermakna ganda. Ucapan "Terima kasih" dapat berupa imbalan dalam bentuk yang lain dan bukan hanya sekedar kata-kata saja. Melainkana da tindakan pemberian imbalan lain, seperti halnya dikaitkan keterhubungan teks sebelumnya, 'imbalan' yang dimaksud seperti jaminan hidup untuk anak dan istri, keuangan, serta bisnis yang masih tetap berjalan lancar.

Adapun dijelaskan pula beberapa imbalan lain yang dituliskan dalam cerpen ini seperti:

"Masih bisa berkomunikasi dengan keluarga, dan istrinya bisa sewaktu-waktu menemui bila memang ia membutuhkan untuk 'menyelesaikan hasratnya'. Bila merasa bosa dan kepingin sedikit refreshing berjalan-jalan di luar, semua prosedur formal akan dibereskan dengan biaya secukupnya'.

Seperti halnya penggunaan kalimay 'menyelesaikan hasratnya' dalam akna denotasi dapat dimaknai sebenarnya sebagai menyelesaikan keinginan. Seperti kata hasrat merupakan keinginan. Namun dapat cerpen ini, makna konotasi yang terungkap dari kata 'menyelesaikan hasratnya' di konotasikan sebagai makna kebutuhan seksual dari penghuni lapas koruptor. Sebagaimana dala suatu hubungan suami istr seperti dalam kata "Istri bisa sewaktuwaktu menemui" yang dalam artian bahwa keberadaan istri bisa menemui suaminya di penjara kapan pun, dan bila suami berkeinginan untuk bersenggama dnegan istri, seperti penegasan kata "menyelsaikan hasrat; atau pemuasan kebutuhan seksual, maka bisa dilakukan di suat $\mathrm{u}$ tempat khusus yang ada dilingkup penjara tersebut.

Begitu pula penggunaan kata "refreshing" yang dalam makna denotatif berarti berekreasi atau mencari hiburan diluar dan melepaskan semua urusan bisnis, pekerjaan maupun pendidikan. Namun dalam makna konotasi, dari kata 'refreshing' disini dapat diartikan sebagai keinginan untuk keluar dari penjara sewaktu-waktu tanpa harus menunggu masa pembebasannya dan hal tersebut mudah dilakukan dengan suatu bentuk imbalan berupa uang atau ada pembayaran khusus untuk bisa keluar sewaktu-waktu.

Ditegaskan pula makna tersebut dalam kalimat berikut:

"Semua prosedur formal akan dibereskan dengan biaya secukupnya'

Dalam makna konotasi disini "Prosedur formal" yang terkait dengan persoalan administrasi formal namun bersifat ilegal yang cenderung membiarkan para napi koruptor untuk bisa bebas melakukan apa saja meskipun masih belum berstatus bebas. Meski adanya tindakan bebas yang bisa dilakukan oleh napi koruptor, namun tidak sepenuhnya bebas lantaran diwajibkan untuk mengurus administrasi dan harus membayar dengan sejumlah uang untuk menutupi keburukan dari tindakan koruptor yang merasa bebas diluaran tanpa pengawasan dari aparat hukum.

Pemaknaan konotasi pada cerita Lelucon para koruptor dikemas dalam ragam bahasa dan varian kata. Seperti halnya dengan istilah 'kawan satu sel' yang 
dalam makna denotasi dalam disebut dengan teman dalam satu ruangan sel penjara, namun divariasikan dengan beberapa makna konotasi seperti teman yang memiliki latar belakang dan nasib yang sama. Namun beberapa varian yang digunakan dalam cerpen ini seperti 'teman sekamar' ataupun 'teman satu apartemen'. Penggunaanistilah ini merujuk pada istilah yang digunakan pada kelas sosial atas yang menggunakan istilah 'teman satu apartemen', yang dimana penggunaan istilah apartemen atau tempat tinggal yang terdiri dari rumah yang tersusun bagi kalangan elit atau untuk orang kaya yang memiiki fasilitas lengkap. Makna denotasi ini menjadi kontras lantaran penjara bukanlah apartemen, tentu saja dalam penegrtian sebenarnya penjara untuk kalangan penjahat atau mendapat predikat kriminal, sementara apartemen adalah hunian sipil untuk kategori orang-orang yang mampu bertempat tinggal di apartemen. Begitu pula penggunaan istilah 'kawan satu kamar' yang diartikan sebagai teman dalam satu ruangan yang nyaman seperti privasi.

Dalam konotasinya, dapat dimaknai bahwa penjara bagi kalangan para koruptor diupayakan berbeda dengan penjara pada umumnya untuk penjahat kelas rendah. Penjara koruptor seperti halnya sebauh apartemen yang mewah, atau dengan kata lain penjara yang digambarkan bentuknya lebih bagus dibandingkan penjara kelas rendah yang tidak memiliki fasilitas apapun. Selain itu kenyamanan pada penjara koruptor digambarkan begitu berbeda dengan penjara koruptor yang menawarkan kenyamanan lebih baik dibanding penjara biasa.

Pada babak kedua perbincangan antara Otok dengan Sarusi yang merupakan salah satu penghuni penjara dan juga ditetapkan sebagai tersangka korupsi yang berada dalam satu sel. Pada babak cerita ini juga menceritakannya dalam bentuk narasi dan dialog. Konten cerita lebih banyak menceritakan tentang ketentuan dan kesepakatan menjadi napi koruptor di lapas yang mengharuskan setiap napi koruptor untuk membuat lelucon atau bahan candaan untuk diperbincangkan dalam pertemuan antar napi koruptor di hari tertentu.

Dalam perbincangan ini juga mencakup beberapa tanda-tanda penting pada bahasa seperti dialog "Kau bisa berkenalan dengan orang-orang terhormat" yang dalam makna konotasinya bahwa para koruptor digambarkan sebagai orang yang terhormat dan memiliki derajat yang tinggi. Selain itu juga pertemanan dengan koruptor dimaknai sebagai bentuk relasi yang tingkat tinggi atau relasi berkelas yang tidak mudah ditemui diluar penjara koruptor.

Hal lain yang menjadi makna berkesinambungan namun juga variatif dalam membangun sebuah perkataan seperti kalimat:

"Disini kamu justru punya banyak kesempatan untuk membangun koneksi."

Dalam makna denotasi, di penjara merupakan peluang dan kesempatan untuk membangun jaringan dengan penghuni penjara lainnya. Namun pada makna konotasi dapat dimaknai bahwa penjara menjadi sarana untuk membangun jaringan khusus dan menjadi suatu peluang besar, serta membentuk sebuah relasi pertamanan. Tentu hal ini kontras dengan kondisi penjara pada umumnya yang membuat para tahanan justru makin kehilangan banyak koneksinya dan bahkan tidak memiliki 
kesempatan untuk berteman karena digambarkan bahwa penjara adalah tempat menakutkan.

Dalam babak ketiga yaitu berisikan humor-humor yang dimasukkan dalam percakpan antar para koruptor dalam sebuah pertemuan para penghuni penjara koruptor. Adapaun beberapa lelucon yang dimunculkan seperti berikut:

\section{Tabel 1}

\section{Kalimat -kalimat "Lelucon Para Koruptor"}

\begin{tabular}{|c|c|}
\hline Kalimat Lelucon & Makna \\
\hline Ada pesawat Boeing & Memiliki makna \\
\hline 747 mengangkut 560 & bhawa anggota DPR \\
\hline Anggota DPR, & tidaklah \\
\hline Pimpinan DPR, 5 & sebagai perwakilan \\
\hline Sekretaris DPR, 12 & rakyat, melainkan \\
\hline Ketua Fraksi DPR. & anggota DPR selalu \\
\hline Saat melintasi gunung, & dianggap mengambil \\
\hline $\begin{array}{l}\text { pesawat itu jatuh dan } \\
\text { meledak. Menurut }\end{array}$ & $\begin{array}{l}\text { uang rakyat seperti } \\
\text { halnya }\end{array}$ \\
\hline kalian, siapa yang & direpresentasikan \\
\hline selamat? & koruptor \\
\hline Mendengar itu, murid- & cenderung \\
\hline serempak & mengambil \\
\hline menjawab: & rakyat. \\
\hline selamat & \\
\hline Rakyat Indonesia. & \\
\hline Kenapa di rel kereta & Dalam \\
\hline ditaruh & lelucon \\
\hline batu? Karena kalau & digambarkan bahwa \\
\hline ditaruh duit, pasti & keberadaan \\
\hline $\begin{array}{lll}\text { habis } & \text { diambil } & \text { kita } \\
\text { semua. } & \text { Lelucon } & \text { dari }\end{array}$ & $\begin{array}{ll}\text { dimanapun } & \text { selalu } \\
\text { rentan di mata }\end{array}$ \\
\hline tokoh bernama pak & koruptor untuk \\
\hline Hakil. & $\begin{array}{l}\text { diambil. Dalam cerita } \\
\text { ini lelucon juga } \\
\text { merepresntasikan } \\
\text { koruptor. }\end{array}$ \\
\hline Makin banyak uang & Bagi para koruptor \\
\hline makin terpandang dan & kehormatan \\
\hline disayang. Setidaknya, & paling utama adalah \\
\hline $\begin{array}{l}\text { makin disayang para } \\
\text { sipir penjara. Saya tak }\end{array}$ & $\begin{array}{l}\text { bila memiliki uang } \\
\text { banyak dibandingkan }\end{array}$ \\
\hline
\end{tabular}

\begin{tabular}{|c|c|}
\hline $\begin{array}{l}\text { ersalah. } \\
\text { tya tidak merbukti } \\
\text { ttu rupiah pun, sebab } \\
\text { ang saya terima } \\
\text { dalah } \\
\text { elucon dollar." } \\
\text { ernama mas Unas }\end{array}$ & $\begin{array}{l}\text { semakin banyak ua } \\
\text { yang dikorupsi m } \\
\text { akan sema } \\
\text { menentukan } \\
\text { martabat. }\end{array}$ \\
\hline $\begin{array}{l}\text { api harus diakui, di } \\
\text { tara kita semua, } \\
\text { gawai pajak yang } \\
\text { kan gampang masuk } \\
\text { Irga. Ketika mau } \\
\text { asuk gerbang surga, } \\
\text { ap oran akan ditanyai } \\
\text { alaikat. Nah, ketika } \\
\text { mpai digerbang } \\
\text { Irga, justru pegawai } \\
\text { jak yang malah } \\
\text { enanyai malaikat, } \\
\text { olong perlihatkan } \\
\text { PT pintu gerbang } \\
\text { Irga ini! Apakah } \\
\text { Idah melunasi pajak } \\
\text { ntu gerbang surga?' } \\
\text { lendengar itu, } \\
\text { alaikat cepat-cepat } \\
\text { enyuruh pegawai } \\
\text { jak itu masuk surga, } \\
\text { ar urusan pajak } \\
\text { ggak diungkit- } \\
\text { agkit." }\end{array}$ & $\begin{array}{lr}\text { Dalam } & \text { makna } \\
\text { lelucon } & \text { digambarkan } \\
\text { bahwa } & \text { peranan } \\
\text { pekerja } & \text { pajak } \\
\text { memiliki } & \text { perangai } \\
\text { besar dan } & \text { ditakuti, } \\
\text { bahkan } & \text { dalamm } \\
\text { lelucon } & \text { pun } \\
\text { menggunakan } \\
\text { kelakar yang } \\
\text { menyentuh redikit } \\
\text { yang religius } \\
\text { ebagai dijadikans } \\
\text { candaan. }\end{array}$ \\
\hline $\begin{array}{l}\text { Di negeri ini lebih } \\
\text { ampang jadi orang } \\
\text { aaya ketimbang jadi } \\
\text { rang miskin. Kalau } \\
\text { nau jadi orang } \\
\text { niskin, harus bersaing } \\
\text { lengan } 100 \text { juta orang. } \\
\text { Tapi, kalau mau jadi } \\
\text { rang terkaya, } \\
\text { aingannya hanya } 10 \\
\text { rang. Artinya, kalau } \\
\text { lanti kita keluar, kita } \\
\text { nasih tetap punya } \\
\text { arapan untuk makin } \\
\text { aya karena hanya }\end{array}$ & $\begin{array}{l}\text { Makna } \\
\text { menggambarkan } \\
\text { bahwa pendudk } \\
\text { miskin sangatlah } \\
\text { banyak dibandingkan } \\
\text { dengan orang kaya. } \\
\text { Para koruptor } \\
\text { diibaratakan } \\
\text { mengejar } \\
\text { kekayaan harta } \\
\text { tidak ingin menjadi } \\
\text { bagian dari penduduk } \\
\text { miskin } \\
\text { mensejajarkan } \\
\text { dengan sgeelintir }\end{array}$ \\
\hline
\end{tabular}




\begin{tabular}{|c|c|}
\hline $\begin{array}{l}\text { bersaing dengan } 10 \\
\text { orang. }\end{array}$ & orang kaya tersebut. \\
\hline $\begin{array}{l}\text { Polisi itu selalu } \\
\text { menyelesaikan } \\
\text { masalah tergantung } \\
\text { seberapa gendut } \\
\text { rekeningnya. }\end{array}$ & 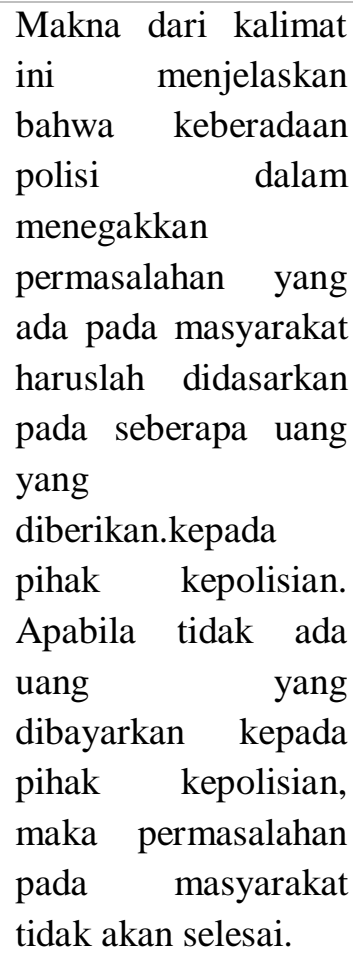 \\
\hline
\end{tabular}

Pada ending cerita cerpen ini juga memberikan suatu penekanan kalimat yang bisa dikatakan cukup menohok dalam menggambarkan salah satu dari realitas korupsi.

"Dalam kasusmu, kamu menutupi banyak fakta, sehingga hanya kamu sendiri yang masuk penjara. Кати melindungi seтиa atasanmu yang terlibat. Oleh mereka yang diselematkanmu, kamu dianggap hebat, pahlawan penyelamat. Tapi, bagi kawan-kawan disini, kamu hanyalah seorang pengecut. Karena tak pernah berani menyebutkan namanama yang ikut korupsi bersamamu."

Pada percakapan terakhir dari cerpen ini sebelum smapai pada tahap penutup, memiliki makna bahwa keberadaan Otok bukanlah sebagai pelaku utama dalam kasus korupsi yang diterimanya. Melainkan dirinya dijadikan sebagai 'tumbal' dari bagian permainan politik para koruptor yang menjadi aktor utama di balik kasus korupsi. Otok sendiri digambarkan sebagai tokoh yang tidak berdaya yang sebenarnya digambarkan sebagai sosok yang lemah yang sebenarnya tidak mampu untuk membuat lelucon dengan para koruptor lainnya.

Dalam cerpen ini menunjukkan adanya suatu gap kelas sosial antara koruptor yang sebenarnya dengan orang yang ditumbalkan sebagai koruptor dan dianggap sebagai kelas rendah karena bukanlah sosok koruptor yang sebenarnya. Hal inilah yang digambarkan dalam cerpen ini bahwa keberadaan koruptor tidak selalu orang-orang yang memang seorang aktor utama dalam pelaku korupsi, melainkan adapula yang memang senagaja dijadikann koruptor agar masuk penjara dan tidak mencolok serta membersihkan nama baik koruptor yang sebenarnya dengan menjadikan orang lains ebagai koruptor dengan diberikan imbalan dan jaminan kenyamanan serta kehidupan yang layak.

Secara keseluruhan makna yang terkandung dalam cerpen "Lelucon Para Koruptor" ini menunjukkan bahwa keberadaan koruptor dalam penjara menunjukkan keragaman. Selain itu kehidupan sehari-hari koruptor di dalam penjara juga tidaklah menakutkan ataupun tidak terikat dalam aturan yang begitu keras seperti halnya penjara sipil pada umumnya. Dalam cerpen ini, digambarkan bahwa para koruptor justru hidup nyaman dan memiliki jaminan kehidupan diluar penjara seperti halnya menjalankan bisnis maupun jaminan kehidupan anak istri.

Selain itu lelucon-lelucon yang dimunculkan pada cerpen ini merupakan sindirna-sindiran terhadap fenomena kasus korupsi yang ada pada realitas kasus yang ada hingga saat ini. Dalam lelucon ini 
terlihat bawha penulis, Agus Noor menggambarkan tentang karakteristik koruptor dengan penamaan tokoh-tokoh koruptor di dalam cerpen yang sebenarnya juga didasarkan pada nama-nama tersangka koruptor yang sudah dikenal di media massa dan juga satir yang diangkat juga mengkolektifkan kasus korupsi sejak tahun 2009 hingga tahun 2018 lalu.

Tentunya sindirian ini juga terlihat sebagai sebuah kritik sosial tentang tata cara berbicara para koruptor, pengkarakteristikan seorang koruptor yang sebenarnya juga begitu dikenal oleh publik, namun hal ini disamarkan oleh sang penulis dengan alasan suatu bentuk etika untuk tidak menyebutkan nama-nama asli dari para tersangka koruptor sebenarnya sehingga secara keseluruhan tokoh-tokoh yang tergambarkanmelalui realitas kasus korupsi ini disamarkan, namun pada akhirnya semakin terlihat dalam makna lelucon yang disajikan dalam humor ini juga menggambarkan realitas yang sebenarnya.

Dalam hal ini relasi satir terlihat sebagai sebuah percampuran ideolologi politik, dan juga seni dalam menyiratkan suatu bentuk lelucon-lelucon yang mudah untuk dipahami oleh orang lain, dan juga bertujuan untuk menghibur, agar bacaan tidak membosankan atau terlalu serius.

Seluruh tanda yang digunakan pada cerpen ini memiliki keterikatakan dan saling keterhubungan satu sama laiinnya. Sehingga dalam cerpen ini meski terbagi menjadi tiga babak, namun dalam suatu bentuk kalimat-kalimat, kata, dan satir yang diuatarakan saling terhubung satu sama lainnya dan bisa membangun benang merah makna yang telah dijelaskan sebelumnya.

Satir dengan kritik sosial digunakan melalui bahasa yang lugas sehingga ekspresi yang dimunculkan olwh penulis pun ditempatkan pada unsur penanda yang bertujuan untuk menunjukkan ciri-ciri dari kisah para koruptor, selain itu ungkapan-ungkapan yang dimunculkan pada lelucon serta narasi pada cerpen "lelucon para koruptor" tersebut merupakan ungkapan-ungkapan subjek atau oleh penulis sendiri dengan mengumpulkan keunikan-keunikan dari karakter paa koruptor yang sebetulnya untuk mendukung kontennya tersebut, mengupayakan suatu bentuk daya tarik publik yang familiar dengan pengkarakteristikan koruptor. Sehingga tanda-tanda bahasa yang digunakan pada teks tertulis ini bertujuan sebagai penekanan makna dan juga kandungan makna juga memfungsikan satir sebagai instrumen kritik sosial terutama bagi kritik sosial.

\section{KESIMPULAN}

Melalui analisis semiotika dengan model Louis Hjlemslev, ditemukan bahwa relasi bahasa satir dengan kritik sosial disini terletak pada penggunaan tanda-tanda bahasa yang merupakan sebuah eskpresi yang dilakukan melalui pemilihan kata-kata yang digunakan untuk menggambarkan karakteristik dari para koruptor dengan keciri khasannya dan juga pengkarakteristikan koruptor dalam esensi sosialnya. Hal ini dilakukan oleh penulis dengan menyesuaikan dengan realitas kasus korupsi yang ada di Indonesia dengan mengkolektifkan kasus-kasus yang beredar di media massa dan familiar di mata publik.

Kritik yang dibangun oleh penulis disini merupakan kritik yang berkembang 
Radita Gora Tayibnapis: Relasi Bahasa Satir dan Kritik Sosial dalam Cerpen "Lelucon Para Koruptor" Karya Agus Noor

Website : https://jurnal.umj.ac.id/index.php/penaliterasiEmail : penaliterasi@umj.ac.id

bahwa keadilan masih bersifat lemah terutama perlakuan bagi para koruptor yang cenderung lebih diistimewakan, hingga menempatkan orang lain sebagai tersangka korupsi untuk menutupi keborokan pelaku korupsi yang sebenarnya. Melaui satir-satir yang disajikan penulis, maka makna-makna yang terkandung menggambarkan bahwa satir lelucon sebenarnya adalah gambaran yang dianggap sebagai yang realistis dalam tindakan korupsi meskipun dibalut dengan logika.

\section{DAFTAR PUSTAKA}

Ajidarma, Seno Gumira. (2012). Antara Tawa dan Bahaya (Kartun dalam Poltiik Humor). Jakarta: Kompas Gramedia Pustaka.

Kridalaksana, Harimurti. (2005). MonginFerdinand de Saussure: Peletak Dasar Strukturalisme dan Linguistik Modern. Jakarta: Yayasan Pustaka Obor Indonesia.

Noor, Agus. (2017). Lelucon Para Koruptor (Kumpulan Cerpen). Yogyakarta.
Ricouer, Paul. (2014). Teori Interpretasi: Membelah Makna dalam Anatomi teks. Yogyakarta: IRCiSoD.

Rusmana, Dadan. (2014). Filsafat Semiotika (Paradigma, teori, dan metode interpretasi tanda, dari semiotika struktural hingga dekonstruksi praktis). Bandung: Pustaka Setia.

Sobur, Alex. (2006). Analisis Teks Media (Analisis Wacana, Framing dan Semiotika). Bandung: Remaja Rosdakarya.

Wellek, Renẽ \& Austin Warren. (2016). Teori Kesusastraan. Diterjemahkan oleh Melani Budianta. Jakarta: Penerbit Gramedia Pustaka.

Wibowo, Indiwan Seto. (2013). Semiotika Komunikasi: Aplikasi Skripsi bai Penelitian dan Skripsi Komunikasi. Jakarta: Mitra Wacana Media 